
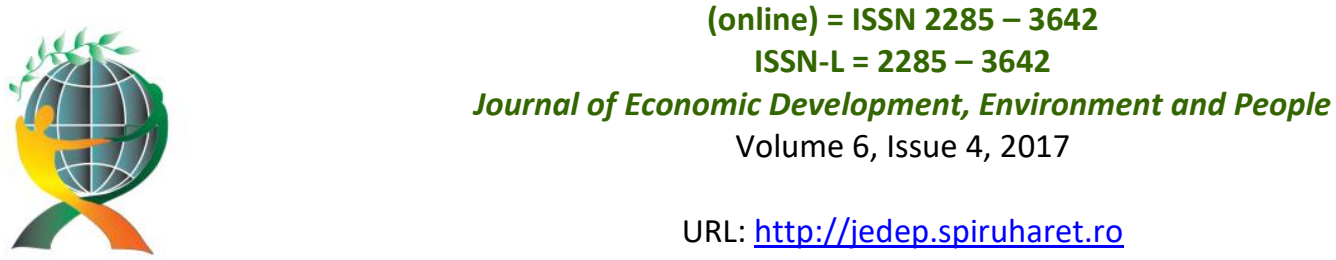

\title{
Analyzing the Impacts of Restructuring on the Turkish State-Owned Banks ${ }^{1}$
}

\author{
Gazi Sarısakaloğlu², Mustafa Bilgin ${ }^{3}$ \\ ${ }^{2}$ Hitit University, Institute of Social Sciences, Economics Department, Çorum, Turkey \\ ${ }^{3}$ Hitit University, Faculty of Economics and Administrative Sciences, Çorum, Turkey
}

\begin{abstract}
The subject of this research is to compare the performance based on determined criteria of the state owned banks in Turkey before 10 years and after 14 years from 2001 the date they were included in a restructure program. The t-test method is used in the study. According to the results of the analysis, it was concluded that the most successful state-owned bank was Halkbank with a small margin in front of Ziraat Bank after the year that the restructuring program was implemented. Ziraat Bank, as well as having the second most positive development of public banks in terms of analysis ratios, it has almost equal proportions with Halkbank in terms of asset quality and branch ratios. Halkbank is ranked first as usual in terms of branch ratios. All state owned banks are subject to the close rates for branch ratios. When evaluating the performance of public banks in general over a total of 36 criteria, they showed positive development for 26 criteria. That means after the restructuring program that we called 2nd period in the study public banks became more successful based on established criteria.
\end{abstract}

Key Words: Bank, State Owned Bank, Restructuring of State-Owned Banks, Banking Sector.

JEL Codes: G21, G28, G34

\footnotetext{
${ }^{1}$ This study is produced from the Master Thesis prepared by Gazi Sarısakaloğlu, supervised by Assistant Professor Mustafa Bilgin and presented to Hitit University Institute of Social Sciences.

${ }^{2}$ Hitit University Institute of Social Sciences, Economics Department, Çorum, 19260, Turkey, Tel:+90 3642350620 , Fax:+90 0364235 0621, Email: gsarisakaloglu@ziraatbank.com.tr.

${ }^{3}$ Assistant Professor. Hittit University Faculty of Economics and Administrative Sciences, Çorum, 19260, Turkey, Tel:+90 364235 0620, Fax:+90 0364235 0621, Email: mustafabilgin@hitit.edu.tr.
} 


\section{Introduction}

After the great economic crisis spread to the whole world international sizes in 1929, the prevailing economic thinking in the world was Keynesian Economic Thought System. According to this opinion the private sector alone cannot provide the capital adequacy to reach the desired level of industrialization in the national economy, and the state should take place more effectively to achieve the economic goals and to implement the economic policy was advocated. In this regard there are similitudes with other countries [Baicu, 2017].

The economic crisis spread all over the world in 1929, the deterioration over the international trade balance, foreign exchange, the supervisory procedures applied in foreign exchange transactions and the other similar problems required radical changes in Turkey's economic policy in that period. These economic developments have made necessary to apply different policies in many sectors including banking sector. Under these developments, large-sized state-owned banks have been established between the years 19301940 [Akgüç, 2007].

The aim of establishing these banks to carry out or finance capital investments and industrialization cannot be met through the private sector [Atasoy, 1993]. The state owned banks founded by special law mainly aimed to transfer the economic resources to the areas that given priority by state. They were established to support the industry investments because private banking structure was insufficient in achieving these goals [Uçarkaya, 2006].

State owned banks have established with these purposes which were failed in 1980s to adapt to global economic developments and competition. These banks have been continued their activities in the public interest for many years but by the time, they became a kind of institutions that hurt and burden to the public.

In 2000s, Turkey has experienced economic crisis adversely affecting the entire economy moreover the banking sector was the mainly affected. After these crises happened, the troubled banks including state owned banks, were removed from the system or were taken in a restructure program in order to restore them. As a part of restructuring program to strengthen the financial structure of the banking system and to increase the effectiveness of control mechanisms, the international regulations have been implemented.

In May 2001 a comprehensive package of reforms announced concerning the Turkish banking sector by BDDK (Banking Regulation and Supervision Agency) to solve the problems of these troubled banks that were affected adversely from the November 2000 and February 2001 crisis. It was aimed to ensure the achievement of a healthy and strong structure in banking sector in Turkey.

As a part of restructuring works, some of the state-owned banks which have been damaging the financial sector had been liquidated or exposed to a merger or decided to be privatized. The state owned banks that agreed on restructuring were Ziraat Bank, Halkbank and Vakıflar Bank. The objective of this study is to analyze the performance of these state owned banks were included reconstructing program and not privatized yet in terms of the determined criteria before and next the reconstruction decision.

\section{Purpose of The Study}

Intermediary institutions in the financial system in Turkey are the Participation Banks, Commercial Banks, Development and Investment Banks, Brokerage Houses, Stock Exchanges, Investment Consultancy Companies, Factoring Companies, Portfolio Management Companies, Forfeiting Companies, Consumer Finance Companies, Leasing Companies, Insurance Companies, Social Security Institutions and Individual Pension Companies. Within the financial system, the importance of banks is bigger than other financial institutions [Bayraktaroğlu, 2013]. 


\author{
(online) $=$ ISSN $2285-3642$ \\ ISSN-L = $2285-3642$ \\ Journal of Economic Development, Environment and People \\ Volume 6, Issue 4, 2017
}

URL: http://jedep.spiruharet.ro

e-mail: office_jedep@spiruharet.ro

The share of the banking sector in Turkey is an important level within the financial system. After the 1950s, the emerging economic system in Turkey had a structure that is active in the banking sector. So much so that, the sector affected mostly from the economic policies implemented at 1980 s was banking sector.

The increasing pace of globalization since the 1980s and 1990s brought together the integration of financial markets in the world economy [Erçel, 2000]. However, the cultural and economic boundaries between the countries have gradually decreased.

It is defined as periods of liberalization and globalisation in banking between 1980 and 2001. For adaptation to globalization and liberalisation, some kinds of policies added to the economic package which was announced at the January 24, 1980 Stability Program ${ }^{4}$ [Akgüç, 2007]. As a result of globalization and the market economy target set in this period, legal regulations have been made to public banks to operate on the same conditions as other banks.

Banking sector in Turkey is the most important and the biggest part of financial sector. In Turkey, the size of the banking sector within financial markets has grown steadily over the years, but it still maintains this magnitude today [Coşkun, 2012].

After the policies and regulations implemented, changes were made in the banking system, which had a restrictive structure such as establishing a bank and increasing the number of branches until 1980. It is aimed to increase competition and efficiency in the sector by facilitating transactions such as the establishment of commercial banks and increasing the number of branches of foreign banks.

In the economic package, known as the April 5th Decisions of 1994, regulations were made that closely related to the banking system.

The problems that existed in the banking sector in 2000 years; inadequate loan and deposit ratios, the fact that the number of small banks in the sector is larger than the number of big banks, the sectoral dominance of state owned banks and the financial institutions that are in the process of being damaged and lacking in control and audit mechanisms in the sector. In addition, there were economic problems such as long-term guarantees for savings deposits are state-based, making the domestic borrowing heavily in the public and private sectors from the banks, bad exchange rate policies in foreign exchange transactions and using the resources of the public banks for the political authorities in their own interests [Ercan, 2005]. These problems have further increased the adverse effects of emerging crises on the Turkish banking

\footnotetext{
${ }^{4} 24$ January 1980 Stability Program; It is a work initiated in the lead of Turgut Özal, the Minister of State and the Deputy Prime Minister about the whole economic regime which provides for the transition of the national economy to the market economy, the liberalization of the economy and the adjustment to the capitalist system, the reduction and control of the private sector intervention of the public, and the spontaneous formation of interest rates by the market, not by the state.
} 
sector. The fact that the Turkish banking system is not in a sound legal, operational and financial grounds have increased the sensitivity of the banking sector to the economic crises experienced.

After the banking crises that emerged in 1999-2001 in Turkey, there have been developments that can be regarded as positive after the restructuring studies in the financial sector started and a difficult implementation period. In this development and growth process, the banking sector has been the most important building block of the financial system.

Banks, whose main objectives are to transfer the funds they provide from those with more than their funding to those who need it, contribute to the growth of financial volume and the increase in national income and employment. Macro functions of banks are; to transfer resources to the sectors and fields in need of the economy, to support the implementation of monetary policy, and to help the country's economies to integrate and develop in foreign trade transactions [Bayrakdaroğlu, 2013].

The public banks that continue to operate in Turkey are Ziraat Bank, Halkbank, Vakıflar Bank.

The main purpose of this study is to measure the performances of 3 state owned banks engaged in deposit banking operating across Turkey. They were measured in terms of their performances of 10 years before restructuring process and also 14 years after restructuring process. The other purposes are;

- The evaluation of public banks' performance before and after the 2001 crisis on a bank basis over certain ratios,

- The differences in the restructuring process implemented in 2001 on public banks, Ziraat Bank, Halkbank and Vakıflar Bank,

- The expression of sector shares and sectoral activities of public banks over the past years with specific criteria and graphical representations.

\section{Limitations of The Study}

The performance of state-owned banks between the years 1990-2000 was called first period. The performance between the years 2002 to 2014 are expressed in the form of the second period in the research. In order to have a more solid foundation of this practice, the adverse effects of the 2001 economic crisis occurred in Turkey in banking sector was deemed appropriate to exclude of the research. Therefore, the 2001 ratios were not included in study.

\section{Methods Used in Research and Data Analysis}

The analysis system of the research called t-test is a method that helps to evaluate the differences between the two groups either it is incidental or statistically significant [Akdağ, 2011].

Independent sample t-test, the type to be used in the study means comparing the average of two independent groups mutually which were determined according to dependent variable. While making this comparison a certain level of confidence is determined and it is tested; either there is a significant difference over the confidence interval or not [Ural, 2006].

Before the restructuring in the study, the data for the first semester was evaluated as the first group, and the data for the second semester was evaluated as the second group. For this reason, it is considered appropriate to have a t-test for the method of the study.

The averages of the ratios calculated over certain criteria were compared among the groups.

The Independent Sample, which is the type of t-test to be used in the study; is the reciprocal comparison of the mean of the two independent groups determined by a dependent variable. In this comparison, a certain level of confidence is determined and tested to see if there is a significant difference over this confidence interval [Akdağ, 2011].

The confidence intervals and significance levels determined in the study are as follows; 


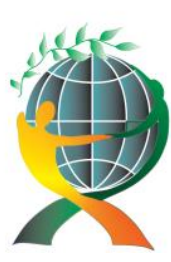

\author{
(online) $=$ ISSN $2285-3642$ \\ ISSN-L = $2285-3642$ \\ Journal of Economic Development, Environment and People \\ Volume 6, Issue 4, 2017 \\ URL: http://jedep.spiruharet.ro \\ e-mail: office jedep@spiruharet.ro
}

sin. $<0,01 \Rightarrow \% 1$ There is a significant difference in the $99 \%$ confidence interval from the Independent Sample t test.

sin. $<0,05=>\% 5$ There is a significant difference in the $95 \%$ confidence interval according to the Independent Sample t test.

$\sin .<0,1=>\% 10$ There is a significant difference in the $90 \%$ confidence interval according to the Independent Samples t test.

$\sin .>0,1=>$ There is no significant difference from the Independent Sample $t$ test.

$1 \% \% 99$ Confidence Interval

$5 \%$ \%95 Confidence Interval

$10 \% \% 90$ Confidence Interval

The established hypothesis based on the obtained confidence interval and level of significance will be expressed as follows;

Ho: Group averages are not different from each other.

H1: Group averages are different from each other.

\title{
5. Data Collection Tool
}

Some of the data used in this study are provided from the website of The Banks Association of Turkey directly or obtained as calculated by author using the ratios about the banks.

When the valuation criteria for the research are determined, ratios are preferred to ensure monitoring of changes and development processes of problematic aspects of these banks after reconstruction. These data and ratios used in this study are the most widely used in the measurement of bank performance in literature: Equity/Assets, Total Loans/Assets, Total Loans/Deposits, Non-Performing Loans/Total Loans and Receivables, Net Profit/Equity, Net Profit/Assets, Net Profit/Capital, Per Branch Assets Average, Per Branch Deposits Average, Average Credit Per Branch, Per Branch Employee Average, Per Branch Net Profit Average.

The Asset Quality, Profitability and Branch Ratios used in the survey to measure performance indexes of public banks are explained below. Four active quality ratios, three profitability ratios and five branch ratios were used. 


\section{Results of Analysis}

By using the determined ratios, it is examined in this study that whether the state owned banks in Turkey has a positive improvement and significant differences before and after the restructuring. Results obtained by using the ratios are shown in Table 1.

The results obtained by using t-test are signed as accepted and refused. Accepted means there is significant differences between two periods in this study (Table 2).

According to analysis results when we compare the 1 st and the 2 nd period due to the performance ratios of public banks, there are more of the criteria which have significant differences between terms. That means after restructuring program the state owned banks have been more successful than the previous period.

Table 1: According to The Independent Sample t-test The Results of Halkbank, Ziraat Bank and Vakıflar Bank

\begin{tabular}{|c|c|c|c|c|c|c|c|}
\hline & \multirow{2}{*}{\multicolumn{2}{|c|}{$\frac{\text { Halk Bank }}{\text { t-test for Equality of }}$}} & \multirow{2}{*}{\multicolumn{2}{|c|}{\begin{tabular}{|r|} 
Vakıflar Bank \\
r Equality of Means
\end{tabular}}} & \multirow{2}{*}{\multicolumn{2}{|c|}{$\frac{\text { Ziraat Bank }}{\text { t-test for Equality of }}$}} \\
\hline & & & & & & & \\
\hline & & $\mathbf{t}$ & $\begin{array}{l}\text { Sig. (2- } \\
\text { tailed) }\end{array}$ & $\mathbf{t}$ & $\begin{array}{l}\text { Sig. (2- } \\
\text { tailed) }\end{array}$ & $\mathbf{t}$ & $\begin{array}{l}\text { Sig. (2- } \\
\text { tailed) }\end{array}$ \\
\hline \multirow{2}{*}{ Equity / Assets } & Equal variances assumed & $-5,222$ &, 000 & $-6,369$ &, 000 & $-3,508$ &, 002 \\
\hline & Equal variances not & $-4,749$ & ,001 & $-6,703$ &, 000 & $-3,209$ & ,008 \\
\hline \multirow{2}{*}{$\begin{array}{c}\text { Total Loans / } \\
\text { Assets }\end{array}$} & Equal variances assumed & $-2,160$ & ,043 & $-1,708$ & ,102 & 1,893 &, 072 \\
\hline & Equal variances not & $-2,363$ & ,030 & $-1,841$ & ,081 & 1,944 & ,066 \\
\hline \multirow{2}{*}{$\begin{array}{l}\text { Total Loans / } \\
\text { Deposits }\end{array}$} & Equal variances assumed & $-1,942$ & ,066 & $-1,189$ & ,248 & 1,755 &, 094 \\
\hline & Equal variances not & $-2,093$ &, 050 & $-1,205$ & ,242 & 1,796 &, 087 \\
\hline \multirow{2}{*}{$\begin{array}{c}\text { Non-Performing } \\
\text { Loans / Total } \\
\text { Loans and } \\
\end{array}$} & Equal variances assumed & 4,606 &, 000 & 2,338 & ,029 & 1,816 &, 084 \\
\hline & Equal variances not & 4,013 &, 003 & 2,384 &, 027 & 1,999 &, 062 \\
\hline \multirow{2}{*}{ Net Profit / Equity } & Equal variances assumed & $-8,845$ & ,000 &, 581 &, 567 &,- 892 &, 383 \\
\hline & Equal variances not & $-9,238$ &, 000 &, 522 & ,612 &,- 805 & ,438 \\
\hline \multirow{2}{*}{ Net Profit / Assets } & Equal variances assumed & $-1,569$ &, $\mathbf{1 3 2}$ & 2,535 & ,019 &, 515 & ,612 \\
\hline & Equal variances not & $-1,418$ & ,184 & 2,241 &, 049 & ,459 & ,656 \\
\hline \multirow{2}{*}{$\begin{array}{l}\text { Net Profit / } \\
\text { Capital }\end{array}$} & Equal variances assumed & $-3,629$ &, 002 &, 654 &, 520 & $-2,221$ & ,038 \\
\hline & Equal variances not & $-3,990$ & ,001 & ,611 &, 551 & $-2,155$ & ,046 \\
\hline \multirow{2}{*}{$\begin{array}{c}\text { Per Branch } \\
\text { Assets Avarage }\end{array}$} & Equal variances assumed & $-5,602$ &, 000 & $-9,154$ &, 000 & $-7,063$ &, 000 \\
\hline & Equal variances not & $-6,406$ &, 000 & $-10,439$ &, 000 & $-8,063$ &, 000 \\
\hline \multirow{2}{*}{$\begin{array}{l}\text { Per Branch } \\
\text { Deposits }\end{array}$} & Equal variances assumed & $-2,576$ & ,018 & $-1,603$ &, 124 & $-1,172$ & ,254 \\
\hline & Equal variances not & $-2,493$ &, 024 & $-1,429$ & ,183 & $-1,052$ & ,316 \\
\hline \multirow{2}{*}{$\begin{array}{l}\text { Average Credit } \\
\text { Per Branch }\end{array}$} & Equal variances assumed & $-3,789$ & ,001 & $-5,837$ &, 000 & $-3,732$ &, 001 \\
\hline & Equal variances not & $-4,343$ & ,001 & $-6,682$ &, 000 & $-4,277$ &, 001 \\
\hline \multirow{2}{*}{$\begin{array}{c}\text { Per Branch } \\
\text { Employee } \\
\text { Avarage } \\
\end{array}$} & Equal variances assumed & 1,082 & ,292 & 4,669 &, 000 & 17,872 &, 000 \\
\hline & Equal variances not & 1,100 & ,284 & 5,181 &, 000 & 18,648 &, 000 \\
\hline \multirow{2}{*}{$\begin{array}{l}\text { Per Branch Net } \\
\text { Profit Avarage }\end{array}$} & Equal variances assumed & $-5,508$ &, 000 & $-9,190$ &, 000 & $-7,713$ &, 000 \\
\hline & Equal variances not & $-6,313$ &, 000 & $-10,464$ &, 000 & $-8,841$ &, 000 \\
\hline
\end{tabular}




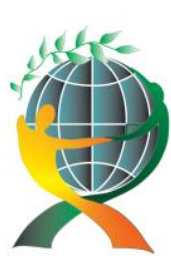

\author{
(online) $=$ ISSN $2285-3642$ \\ ISSN-L = $2285-3642$ \\ Journal of Economic Development, Environment and People \\ Volume 6, Issue 4, 2017
}

URL: http://jedep.spiruharet.ro

e-mail: office jedep@spiruharet.ro

Table 2: Resulting According to Significance Level

\begin{tabular}{|c|c|c|c|c|c|c|c|c|c|c|c|c|}
\hline Banks & $\begin{array}{l}\text { Equity / } \\
\text { Assets }\end{array}$ & $\begin{array}{l}\text { Total } \\
\text { Loans / } \\
\text { Assets }\end{array}$ & $\begin{array}{c}\text { Total } \\
\text { Loans/De } \\
\text { posits }\end{array}$ & $\begin{array}{c}\text { Non- } \\
\text { Performing } \\
\text { Loans/Total } \\
\text { Loans and } \\
\text { Receivables }\end{array}$ & $\begin{array}{c}\text { Net Profit / } \\
\text { Equity }\end{array}$ & $\begin{array}{c}\text { Net } \\
\text { Profit/Ass } \\
\text { ets }\end{array}$ & $\begin{array}{c}\text { Net } \\
\text { Profit / } \\
\text { Capital }\end{array}$ & $\begin{array}{c}\text { Per } \\
\text { Branch } \\
\text { Assets } \\
\text { Average }\end{array}$ & $\begin{array}{c}\text { Per } \\
\text { Branch } \\
\text { Deposit } \\
\text { Average }\end{array}$ & $\begin{array}{c}\text { Average } \\
\text { Credit Per } \\
\text { Branch } \\
\text { Average }\end{array}$ & $\begin{array}{c}\text { Per } \\
\text { Branch } \\
\text { Employee } \\
\text { Average }\end{array}$ & $\begin{array}{c}\text { Per } \\
\text { Branch } \\
\text { Net Profit } \\
\text { Average }\end{array}$ \\
\hline Halk Bank & Accepted & Accepted & Accepted & Accepted & Accepted & Refused & Accepted & Accepted & Accepted & Accepted & Refused & Accepted \\
\hline Ziraat Bank & Accepted & Accepted & Accepted & Accepted & Refused & Refused & Accepted & Accepted & Refused & Accepted & Accepted & Accepted \\
\hline Vakıflar & Accepted & Refused & Refused & Accepted & Refused & Accepted & Refused & Accepted & Refused & Accepted & Accepted & Accepted \\
\hline
\end{tabular}

\title{
7. Conclusion
}

The basic tasks of establishment of public banks in Turkey are to lead the economy in financial matters, to assist in solving the problems in the banking sector, transporting the banking services in rural areas and to contribute to the economy in areas such as financial and fiscal stability.

However, the public banks that have been established have started to engage in activities other than their duty purposes, to make decisions in the direction of political pressures or to allocate resources, to employ unnecessary and inefficient personnel and thus they had begun to damage the economic system. These drawbacks have led to the impossibility of collection and repatriation of a significant portion of the loans granted by public banks; they have caused the falling of banks' performances. The operating objectives of the public banks operating under these conditions have become diverse and public banks have moved away from the profit motive. The inadequacy of information technology and the fact that they have very weak infrastructure in terms of audit has also played an important role in the event that these banks can easily go bankruptcy and they become harmful for banking sector.

The main purpose of public banks is to lead financial markets in many countries in the world as well as economic development in Turkey, to help the sector to solve problems in the banking system, to contribute to the economy of the banking services in rural areas and especially financial and financial stability. However, over time, these banks have failed to keep up with economic development and deepening, and have begun to exercise influence over the financial system. 
The state owned banks in Turkey had irregular balance structure and became unable to continue their basic tasks during 2000s, due to the crisis in 2000 and 2001. Therefore, these banks are included in banking restructuring program implemented in the financial sector for the purpose of resolving the problems of them. In this context, primarily duty losses of these banks were paid and capital support was provided to these banks. The interest rates of the banks have been harmonized to the market as both deposit and lending thus financial restructuring process was completed.

One of the other important restructure issues of these banks is the implemented arrangements to ensure compliance with public sector numbers and international standards about loans, deposit and nonperforming loans. A number of arrangements have been done to improve the asset quality of these banks. Such as the qualifications of the personnel employed in state-owned banks, the number of branches and employees has been the subject of debate topics and became one of the issues given the importance part of the restructuring.

According to the results of our study evaluating the performance of public banks included the restructuring program; over the 12 ratios in the study, 10 criteria of the Halkbank, 9 criteria of Ziraat Bank and 7 criteria of Vakıflar Bank were found to be positive differences to be statistically compared to the previous period. It has been concluded that there is a small margin difference between the Halkbank and Ziraat Bank in terms of performance in state-owned banks and Halkbank is the most successful state owned bank according to the analysis. Ziraat Bank, as well as having the second most positive development of public banks in terms of analyze ratios has almost equal proportions with Halkbank in terms of asset quality and branch ratios proportions. Halkbank is ranked first as usual in profitability ratios. In terms of the branch ratios, all public banks are subject to the close level of success rate. Halkbank's branch/employee ratios lagged behind the other two state banks and through the branch/ deposit ratio, it has a better average growth than the others.

The banking sector is one of the most important dynamics in a country's economy. Therefore, as in most countries of the world, public banks have an important share and role in the economy in Turkey as well. Especially, the fact that Ziraat Bank continues to fulfil its intermediary role in agricultural credits and Halkbank continues to its intermediary role in subsidized and other commercial loans granted to Tradesmen and Craftsmen, while successfully fulfilling other banking activities, makes these banks more important in the sector. Other benefits of public banks to the economic system is their services apart from ordinary banking services such as investment and portfolio consultancy, insurance and private pensions, financing in leasing transactions. After the restructuring efforts of the public banks, even if they have damaged the economy for a while, today they are continuing their activities in a profitable and stable manner.

As a result of our study, while the state banks have been assessed as a whole, after the restructuring process in 26 of the total 36 criteria, 3 state-owned banks have been found to show a positive evolution. In this case, it is understood that after the restructuring works in public banks they became more successful in the next process.

Similar to our study, Bağı ı and Rençber analyzed the performance index of Turkey's public and private banks between the years 2006-2012. As a result of the study, they came to the conclusion that Public banks are more profitable than the private banks. Another conclusion of the study is that Halkbank is the most profitable bank in the state-owned banks [Bağcl, 2014].

In the similar nature of the study performed by Altıkulaç, state-owned banks have been subject to performance evaluation between the years 2001-2005 on the basis of 2001. In this study, in parallel with our research it was determined that there have been improvements in public banks after the restructuring program [Altıkulaç, 2006].

The financial status of deposit banks in Turkey was evaluated in 3 groups as private banks, public banks and foreign capital banks by using The Camels Analysis Method based on 2002-2010 years in Ege and 


\author{
(online) $=$ ISSN $2285-3642$ \\ ISSN-L = $2285-3642$ \\ Journal of Economic Development, Environment and People \\ Volume 6, Issue 4, 2017 \\ URL: http://jedep.spiruharet.ro \\ e-mail: office_jedep@spiruharet.ro
}

others' study conducted at 2015. According to the results of the study, it has been determined that the public banks are better than others in capital sufficiency, managerial proficiency, and sensitivity to market risks, foreign capital banks are better than others in active quality and liquidity and private banks are better than others in profitability.

Kandemir and Arıcl have divided deposit banks into three groups according to their ownership structures in their study conducted in 2013. Banks classified as private capital, public capital and foreign capital have compared their financial performances through 19 criteria through The CAMELS analysis method. Banks classified as private capital, public capital and foreign capital have compared their financial performances through 19 criteria through CAMELS analysis method. It is stated that the restructuring initiatives initiated after the crisis of 2001 gave positive results and the works contributed positively to the sector in evaluating the data taken between 2001 and 2010. At the same time, as a result of these studies, the industry has become more cautious [Kandemir and ArıcI, 2013].

Acar and the others used the data envelopment analysis method to compare banks in terms of number of branches, number of personnel, total assets, profitability and total deposits between 2009 and 2013. In comparison, bank groups are divided into 4 groups as domestic, private, public and participation banks. According to the result of the study, the most effective banks are respectively; public banks, domestic private banks, participation banks and foreign-private banks [Acar etc, 2015].

\title{
8. References
}

[1] Acar, M., Erkoç, T. and Yılmaz, B., Türk Bankacılık Sektörü Için Karşılaştırmalı Performans Analizi, Adnan Menderes Üniversitesi Sosyal Bilimler Enstitüsü Dergisi, 2015, p.1.

[2] Akdağ, M., SPSS istatistiksel Analizler, Malatya,2011, p.3.

[3] Akgüç, Ö., Türkiye'de Yabancı Bankalar, Muhasebe ve Finansman Dergisi, 2007, 36: 6-17.

[4] Altıkulaç, E., Kamu Bankalarının Özelleştirilmesi ve Türkiye’de Performanslarının Özel ve Yabancı Bankalarla Karşılaştırılmasına Iliş̧kin Kantitatif Bir Analiz, İstanbul, Marmara University Department of Banking and Insurance, PhD Thesis, 2006, pp.232-251.

[5] Atasoy V., Kamu Iktisadi Teşebbüsleri ve Özelleştirme Sorunları, Ankara, Nurol Matbaacılık, 1993, p.27-28.

[6] Bağcı, H. and Rençber, F.Ö., Kamu Bankaları ve Halka açık Özel Bankaların Promethee Yöntemi ile Karlııklarının Analizi, Aksaray University Journal of Economics and Administrative Sciences, 2014, p. 1.

[7] Baicu, C., \& Mixa, M. (2017). BANKING SYSTEMS IN ROMANIA AND ICELAND: TWO DIFFERENT WORLDS BUT SIMILAR DEVELOPMENT. Journal of Economic Development, Environment and People, 6(2), 24-44. doi:http://dx.doi.org/10.26458/jedep.v6i2.534 
[8] Bayrakdaroğlu, A., Bankacılık ve Sigortacılık Ders Notu, Finansal Sistem Finansal Kurumlar ve Bankalar, 2013, pp. 58.

[9] Coşkun, M., Türkiye’de Bankacılık Sektörü Piyasa Yapısı Firma Davranışları ve Rekabet Analizi, Türkiye Bankalar Birliği Yayınları, İstanbul, 2012, pp. 27-28.

[10] Erçel, G., Küreselleşme Ve Uluslararası Finansal Gelişmeler, Asya Bankalar Birliği Genel Kurulu, İstanbul, 2000, pp. 2- 17.

[11] Kandemir, T. and Arıcı, N., Mevduat Bankalarında Camels Performans Değerleme Modeli Üzerine Karşılaştırmalı Bir Çalışma (2001-2010), Süleyman Demirel Üniversitesi İktisadi İdari Bilimler Fakültesi Dergisi, 2013, pp.61-87.

[12] Uçarkaya, S., Kamu Bankalarının Bankacılık Sistemindeki Rolü, Ankara, The Central Bank of the Republic of Turkey General Directorate of Banking and Financial Institutions, Expertise Proficiency Thesis, 2006, pp.64-65.

[13] Ural, A. and Kılıç, İ., Bilimsel Araştırma Süreci ve SPSS ile Veri Analizi, Ankara, Detay Akademi Anadolu Yayıncılık, 2006, p. 200. 